\title{
Serum glycated albumin as a new glycemic marker in pediatric diabetes
}

\author{
Ji Woo Lee, MD', \\ Hyung Jin Kim, MD', \\ Young Se Kwon, MD, PhD', \\ Yong Hoon Jun, MD, PhD', \\ Soon Ki Kim, MD, PhD', \\ Jong Weon Choi, MD, $\mathrm{PhD}^{2}$, \\ Ji Eun Lee, MD, PhD' \\ Departments of Pediatrics ${ }^{1}$ and \\ Laboratory Medicine ${ }^{2}$, Inha \\ University Hospital, Inha University \\ School of Medicine, Incheon, Korea
}

\begin{abstract}
Purpose: Serum glycated albumin (GA) has been recently used as another glycemic marker that reflects shorter term glycemic control than glycated hemoglobin (HbA1c). Insulin secretory function and glycemic fluctuation might be correlated with the ratio of $\mathrm{GA}$ to $\mathrm{HbA} 1 \mathrm{c}(\mathrm{GA} / \mathrm{HbA1c}$ ) in diabetic adult patients. This study investigated the association of $\mathrm{GA}$ and $\mathrm{GA} / \mathrm{HbA} 1 \mathrm{c}$ ratio with the levels of fasting C-peptide, fasting plasma glucose in type 1 and type 2 pediatric diabetes.

Methods: Total 50 cases from 42 patients were included. The subjects were classified into type 1 diabetes mellitus (T1DM) $(n=30)$ and type 2 diabetes mellitus (T2DM) $(n=20)$ group. The associations among $\mathrm{HbA} 1 \mathrm{c}, \mathrm{GA}$, and $\mathrm{GA} / \mathrm{HbA} 1 \mathrm{c}$ ratio were examined. The relationship between the three glycemic indices and fasting glucose, fasting C-peptide were analyzed.

Results: Mean values of $\mathrm{GA}$, the $\mathrm{GA} / \mathrm{HbA} 1 \mathrm{c}$ ratio were significantly higher in T1DM than T2DM. GA $(r=0.532, P=0.001), \mathrm{HbA} 1 \mathrm{c}(r=0.519, P=0.002)$ and the $\mathrm{GA} / \mathrm{HbA} 1 \mathrm{c}$ ratio $(r=0.409, \mathrm{P}=0.016)$ were correlated with the fasting plasma glucose. Fasting $\mathrm{C}$-peptide level arranged $4.22 \pm 3.22 \mathrm{ng} / \mathrm{mL}$ in T2DM, which was significantly above the values in T1DM $(0.26 \pm 0.49 \mathrm{ng} / \mathrm{mL})$. There were no significant correlation between HbA1c and fasting C-peptide level. However, GA and the GA/HbA1c ratio exhibited inverse correlations with fasting C-peptide level $(r=-0.214, P=0.002 ; r=-0.516, P<0.001)$.

Conclusion: GA seems to more accurately reflects fasting plasma glucose level than HbA1c. GA, GA/HbA1c ratio appear to reflect insulin secretory function.
\end{abstract}

Keywords: Diabetes mellitus, Glycosylated serum albumin, Glycosylated hemoglobin A, Child

\section{Introduction}

Glycated hemogloin (HbAlc) is widely used as the gold standard parameter of long-term glycemic control in diabetic patients. Mean $\mathrm{HbAlc}$ level is associated with the development and progression of diabetic complications. However, the use of $\mathrm{HbAlc}$ has some limitations. For instance, an integrated measurement of plasma glucose concentration during the previous 2 to 3 months is not suited to provide the evidence of earlier glycemic control and several conditions affecting a hemoglogin $(\mathrm{Hb})$ metabolism such as anemia. Moreover it might be difficult that small-scaled values in $\mathrm{HbAlc}$ cannot estimate mean plasma glucose level ${ }^{1-5)}$.

As another marker for monitoring glucose control, glycated albumin (GA) has been recently used. GA is the percentage of serum glycated albumin to total serum albumin and is not affected by the serum albumin level. Since a $50 \%$ reduction of the lifespan of albumin is $2-3$ weeks, GA reflects shorter terms of glycemic control than $\mathrm{HbAlc}^{6-111}$.

Several studies for the relationship between levels of GA and $\mathrm{HbAlc}$ are recently reported in adult diabetic patients. Koga et al. ${ }^{12)}$ revealed that the GA/HbAlc ratio in fulminant type 1 diabetes (FT1DM) could be a better marker for glycemic variability than $\mathrm{HbAlc}$, which serum GA is higher in FT1DM than type 2 diabetes mellitus (T2DM), whereas HbA1c is significantly 
lower. The high $\mathrm{GA} / \mathrm{HbAlc}$ ratio may reflect recent fluctuations in glucose levels and indicated recently increased postprandial glucose levels. There have also been accumulating evidences that the $\mathrm{GA} / \mathrm{HbAlc}$ ratio is more associated with postprandial plasma glucose levels and insulin secretory function than $\mathrm{HbA} 1 \mathrm{c}^{13,14)}$. However, studies for GA and GA compared to $\mathrm{HbAlc}$ in pediatric diabetes have rarely been reported.

The present study investigated whether GA and the GA/ $\mathrm{HbAlc}$ ratio are related to fasting C-peptide and fasting plasma glucose levels in pediatric diabetic patients, particularly comparing type 1 with type 2 diabetes.

\section{Materials and methods}

\section{Subjects}

Among the children with diabetes mellitus (DM) who visited the Department of Pediatrics at Inha University Hospital from October 2012 to September 2013, the subjects who underwent laboratory tests ( $\mathrm{HbAlc}, \mathrm{GA}$, and fasting C-peptide) were included. Patients with liver disease, anemia were excluded. Total 50 cases from 42 patients were included in this study.

\section{Methods}

Clinical data was collected retrospectively from a review of medical records of patients. The subjects were classified into T1DM and T2DM group. Clinical and biochemical parameters on age, height, body weight, body mass index (BMI), BMI standard deviation score (SDS), DM duration, Hb, aspartate aminotransferase (AST), alanine aminotransferase (ALT), serum albumin, fasting glucose, fasting C-peptide, $\mathrm{HbAlc}$, GA, and $\mathrm{GA} / \mathrm{HbAlc}$ ratios were compared between two groups.
BMI values were calculated using the 2007 growth reference tables for Korean children and adolescents of the Korean Pediatric Society and Korea Centers for Disease Control and Prevention ${ }^{15}$.

Serum glucose level was obtained using the hexokinase method with a Hitachi 7600-110 automatic analyzer (Hitachi Instruments Service, Tokyo, Japan). HbAlc level was measured with Tosoh HLC-723 G7 (Tosoh Co., Tokyo, Japan) by highperformance liquid chromatography. Serum GA level was determined by turbidimetric immunoassay using a Hitachi 7180 analyzer (Hitachi instruments service). Serum C-peptide level was measured using immunoradiometric assay with the C-peptide immunoradiometric assay (IRMA) kit (Beckman Coulter, Fullerton, CA, USA).

Correlations among $\mathrm{HbAlc}$, serum $\mathrm{GA}$, and $\mathrm{GA} / \mathrm{HbAlc}$ ratio between groups were investigated. The relationship between three glycemic indices and fasting glucose, fasting C-peptide were analyzed.

\section{Statistics}

All statistical analyses were performed using PASW ver. 18 (SPSS Inc., Chicago, IL, USA). All data are shown mean \pm standard deviation. The independent samples $t$-test was used to compare clinical and biochemical parameters between the two groups. To evaluate the relationship between $\mathrm{HbAlc}$ and $\mathrm{GA}$ and $\mathrm{GA} / \mathrm{HbAlc}$ ratio, linear regression analysis was used. A $P$-value of $<0.05$ was considered statistically significant.

Table 1. Characteristics of the subjects and the laboratory data in type 1 and type 2 diabetic patients

\begin{tabular}{|c|c|c|c|c|}
\hline Characteristic & Total $(n=50)$ & T1DM $(n=30)$ & T2DM $(n=20)$ & $P$-value \\
\hline Age (yr) & $12.50 \pm 3.46$ & $12.03 \pm 4.20$ & $13.20 \pm 1.73$ & 0.182 \\
\hline Gender (male:female) & $23: 27$ & $13: 17$ & $10: 10$ & \\
\hline Height (cm) & $154.85 \pm 15.76$ & $149.54 \pm 17.14$ & $162.81 \pm 8.99$ & 0.001 \\
\hline Weight (kg) & $53.85 \pm 18.58$ & $44.44 \pm 14.18$ & $67.96 \pm 15.30$ & $<0.001$ \\
\hline BMI $\left(\mathrm{kg} / \mathrm{m}^{2}\right)$ & $21.75 \pm 4.83$ & $19.24 \pm 3.17$ & $25.53 \pm 4.46$ & $<0.001$ \\
\hline BMI-SDS & $0.54 \pm 1.08$ & $-0.13 \pm 0.61$ & $1.45 \pm 0.88$ & $<0.001$ \\
\hline DM duration (yr) & $2.99 \pm 3.64(0-13)$ & $4.08 \pm 4.56(0-13)$ & $1.34 \pm 1.32(0-4.33)$ & 0.002 \\
\hline Hemoglobin (g/dL) & $13.95 \pm 1.06$ & $13.76 \pm 0.95$ & $14.25 \pm 1.19$ & 0.152 \\
\hline Albumin (g/dL) & $4.47 \pm 0.37$ & $4.35 \pm 0.37$ & $4.65 \pm 0.30$ & 0.015 \\
\hline AST (IU/L) & $29.85 \pm 26.96$ & $21.56 \pm 7.78$ & $42.43 \pm 38.94$ & 0.05 \\
\hline ALT (IU/L) & $35.65 \pm 49.18$ & $17.25 \pm 11.19$ & $63.25 \pm 68.87$ & 0.018 \\
\hline $\mathrm{FPG}(\mathrm{mg} / \mathrm{dL})$ & $150.68 \pm 76.64$ & $161.56 \pm 86.67$ & $138.44 \pm 64.08$ & 0.380 \\
\hline Fasting C-peptide (ng/mL) & $1.92 \pm 2.87$ & $0.26 \pm 0.49$ & $4.22 \pm 3.22$ & $<0.001$ \\
\hline $\mathrm{HbA1C}(\%)$ & $8.72 \pm 2.46$ & $9.15 \pm 2.45$ & $8.06 \pm 2.39$ & 0.125 \\
\hline Glycated albumin (\%) & $23.38 \pm 10.39$ & $26.33 \pm 10.16$ & $18.96 \pm 9.30$ & 0.012 \\
\hline $\mathrm{GA} / \mathrm{HbA} 1 \mathrm{c}$ ratio & $2.59 \pm 0.50$ & $2.82 \pm 0.34$ & $2.26 \pm 0.52$ & $<0.001$ \\
\hline
\end{tabular}

Values are presented as mean \pm SD or mean \pm SD (range).

SD, standard deviation; T1DM, type 1 diabetes mellitus; T2DM, type 2 diabetes mellitus; BMI, body mass index; SDS, standard deviation score; DM duration, morbidity period for DM; AST, aspartate aminotransferase; ALT, alanine aminotransferase; FPG, fasting plasma glucose; GA/HbA1c, glycated albumin/glycated hemoglobin. 


\section{Results}

\section{Comparison of clinical parameters between the two groups}

A total of 50 cases ( 30 cases in T1DM group and 20 cases in T2DM group) ware analyzed (Table 1). The mean age was $12.03 \pm 4.20$ years in the T1DM group and $13.20 \pm 1.73$ years in the T2DM group $(P=0.182)$. The height, weight, BMI, and BMI-SDS were significantly higher in the T2DM group than in the T1DM group $(P<0.001)$. The average diabetes duration of T1DM group, $4.08 \pm 4.56$ years was longer compared with $1.34 \pm 1.32$ years in the T2DM $(P=0.002)$. Mean fasting C-peptide level in T1DM group $(0.26 \pm 0.49 \mathrm{ng} / \mathrm{mL})$ was lower than in the T2DM group $(4.22 \pm 3.22 \mathrm{ng} / \mathrm{mL}, P<0.001)$. There were no significant differences in fasting glucose and $\mathrm{HbAlc}$ levels between the two groups. The GA level and the GA/ $\mathrm{HbAlc}$ ratio were significantly higher in the T1DM group $(26.335 \% \pm 10.16 \%, 2.82 \% \pm 0.34 \%$, respectively) than in the T2DM group $(18.96 \% \pm 9.30 \%, 2.26 \% \pm 0.52 \%$, respectively) (Fig.
$1)$.

\section{Correlation between $\mathrm{HbA1c}, \mathrm{GA}, \mathrm{GA} / \mathrm{HbA1c}$ ratio in the two groups}

There were significant positive correlations between $\mathrm{HbAlc}$ and GA levels $(r=0.945, P<0.001)$, and HbAlc and the GA/ HbAlc ratio $(r=0.625, P<0.001)$, and GA and the GA/HbAlc ratio $(r=0.882, P<0.001)$. Furthermore, there was a strong significant correlation between HbAlc and GA (Fig. 2). There was no significant correlation between GA and blood $\mathrm{Hb}, \mathrm{GA}$ and AST levels, GA and ALT levels, or GA and serum albumin levels.

\section{Correlation between fasting glucose and each glycemic markers}

There was a positive correlation between fasting glucose and each of the glycemic markers (HbAlc: $r=0.519, P=0.002$; GA:
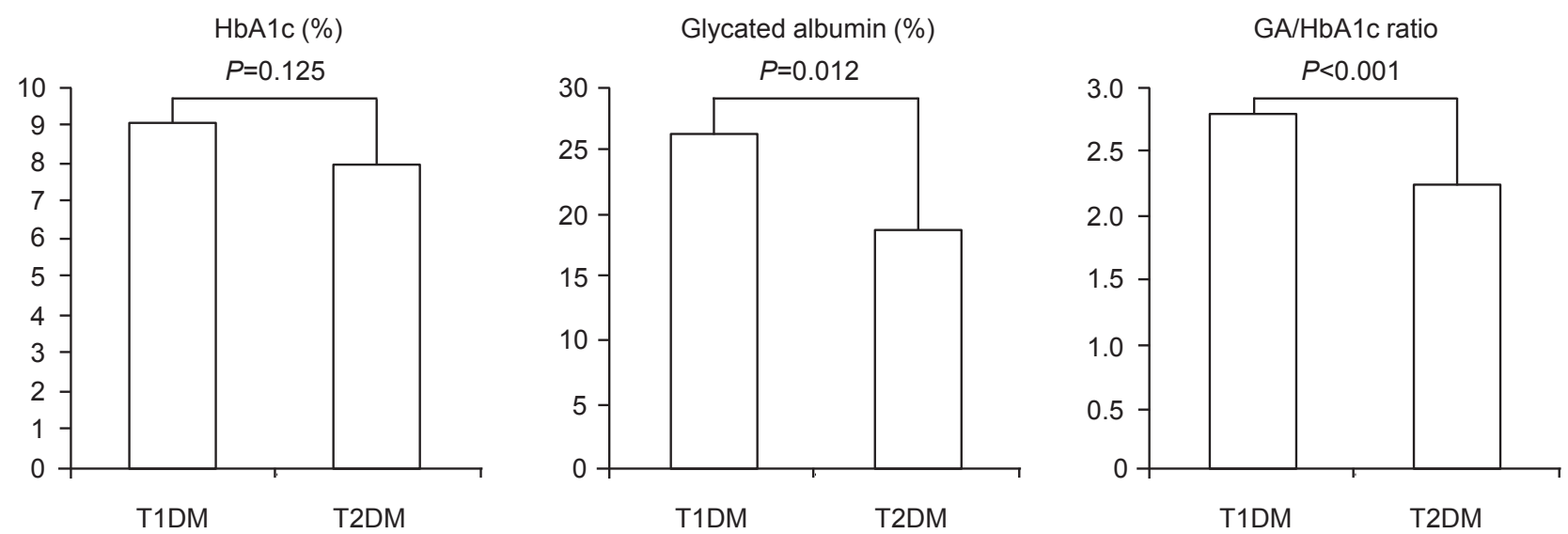

Fig. 1. Glycated hemoglobin (HbA1c) and serum glycated albumin (GA) and the GA/HbA1c ratio in patients with type 1 and type 2 diabetes mellitus (T1DM and T2DM).
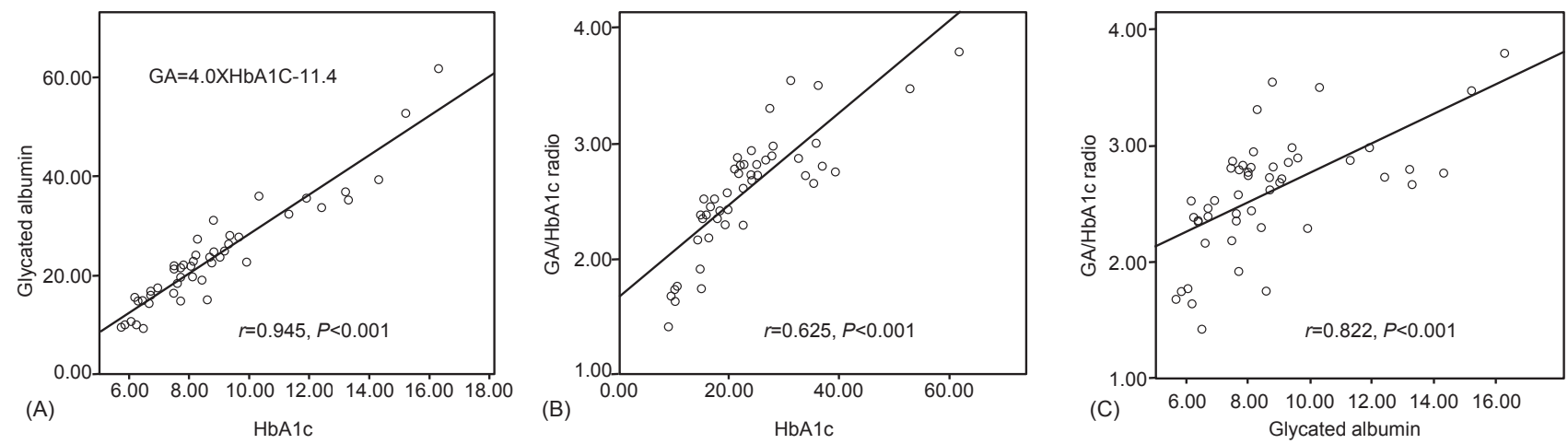

Fig. 2. Correlation between each glycemic markers. There were positive correlations between glycated hemoglobin (HbA1c) and glycated albumin (GA) $(r=0.945, P$ $<0.001)$, HbA1c and the GA/HbA1c ratio $(r=0.625, P<0.001)$, and GA and the GA/HbA1c ratio $(r=0.882, P<0.001)$. 
$r=0.532, P=0.001 ; \mathrm{GA} / \mathrm{HbA} 1 \mathrm{c}$ ratio: $r=0.409, P=0.016)($ Fig. 3$)$.

\section{Correlation between fasting $\mathrm{C}$-peptide and each glycemic markers}

There was a negative correlation between fasting C-peptide and GA levels $(r=-0.214, P=0.002)$, and C-peptide and GA/ $\mathrm{HbA1c}$ ratio $(r=-0.516, P<0.001)$ (Fig. 4.). But HbAlc was not correlated to fasting $\mathrm{C}$-peptide $(P=0.169)$.

\section{Discussion}

Traditionally, HbAlc value has been used to measure longterm glycemic control over the preceding 2-3 months in DM patients. But recent studies have left areas of uncertainty about HbA1c: biological variability and clinical variability. Variability of $\mathrm{Hb}$ lifespan affects the HbAlc levels and the relationship of HbAlc monitoring to microvascular disease in T2DM is not strongly established ${ }^{1-5)}$.

There are other reliable biomarkers for diabetes. The levels of glycated proteins reflect the degree of glycemic control during their life span, which glycation appears throughout the life span of $\mathrm{Hb}$ and serum proteins. Intermediate-term glycemic indicators are fructosamine and serum GA. Fructosamine assay is to measure the sum of all ketoamine linkages resulting from the glycation of circulating serum proteins. Fructosamine has been known to reflect the degree of hyperglycemia over $2-3$ weeks in diabetes, whereas it is affected by serum albumin concentration $^{16-18)}$. GA is the similar to fructosamine excluding it is not affected by serum albumin level, because it is expressed as a percentage of serum albumin ${ }^{13)}$. GA assay can get to be available method in commercial laboratories for clinical application in Korea.

In this study, the GA level and GA/HbAlc ratio were significantly higher in the T1DM group than the T2DM group comparing with no difference of $\mathrm{HbAlc}$ level between the two groups. Recent studies based on the continuous glucose monitoring system (CGMS) data have reported that GA better reflects glycemic fluctuation than HbAlc does ${ }^{11,19,20)}$. CGMS data could not be collected in our study, but based on other study results, the difference of the GA/HbAlc ratio between the T1DM group and the T2DM group can be estimated shortterm glycemic fluctuation of the T1DM group is more severe than that of the T2DM group.
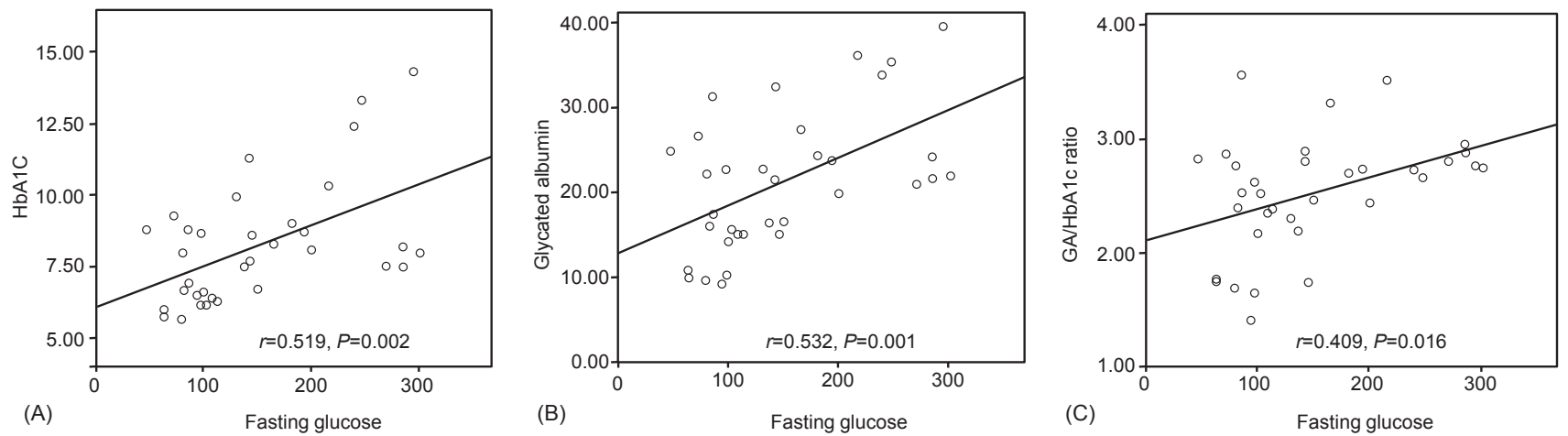

Fig. 3. Correlation between fasting glucose and each glycemic markers. There was a positive correlation between fasting glucose and each of the glycemic markers.
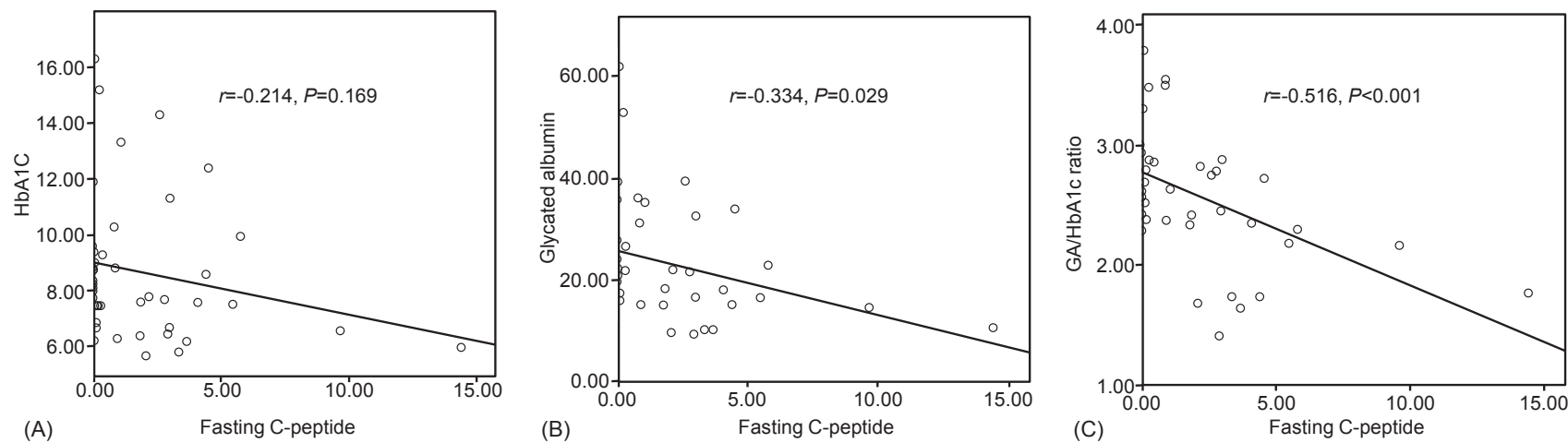

Fig. 4. Correlation between fasting C-peptide and each glycemic markers. There was a negative correlation between fasting C-peptide and glycated albumin (GA) levels $(r=-0.334, P=0.029)$, and C-peptide and GA/HbA1c ratio $(r=-0.516, P<0.001)$ (Fig. 3). But glycated hemoglobin (HbA1c) was not correlated to fasting C-peptide $(r=-0.214$, $P=0.169)$. 


\begin{tabular}{|c|c|c|}
\hline GA (\%) & eHbA1c (\%) & $\mathrm{eAG}(\mathrm{mg} / \mathrm{dL})$ \\
\hline 6 & 4.35 & 78.3 \\
\hline 9 & 5.10 & 99.9 \\
\hline 12 & 5.85 & 121.5 \\
\hline 15 & 6.60 & 143.1 \\
\hline 18 & 7.35 & 164.7 \\
\hline 21 & 8.10 & 186.3 \\
\hline 24 & 8.85 & 207.9 \\
\hline 27 & 9.60 & 229.5 \\
\hline 30 & 10.35 & 251.1 \\
\hline 33 & 11.10 & 272.7 \\
\hline
\end{tabular}

The equation (Table 2) was devised to estimate the average plasma glucose levels using GA levels in order to easily evaluate glycemic control. To derive the relationship between $\mathrm{HbAlc}$ and estimated average glucose, the following formula was used: eAG $(\mathrm{mg} / \mathrm{dL})=28.7 \times \mathrm{HbA} 1 \mathrm{c}-46.7^{21)}$. The correlated formula $\mathrm{GA}=4.0 \times \mathrm{HbA} 1 \mathrm{C}-11.4$, which was obtained from our result, was substituted for this (Fig. 2). This equation, eAG (mg/ $\mathrm{dL})=7.2 \times \mathrm{GA}+35.1$, shows the corresponding values of $\mathrm{GA}$, $\mathrm{HbA1c}$, and eAG. GA 15\% was corresponded to HbA1c 6.6\% and eAG $143.1 \mathrm{mg} / \mathrm{dL}$. The change in s magnitude of GA levels according to changes in glucose levels was larger than that of $\mathrm{HbAlc}$ values. Considering the point, GA can be considered more clinically useful for assessing the estimated glucose values.

This data showed serum GA levels and GA/HbAlc ratios were significantly correlated with $\mathrm{HbAlc}$ levels in pediatric diabetic patients. Otherwise, there was a negative correlation between fasting $\mathrm{C}$-peptide and each glycemic marker, especially the correlation between fasting C-peptide and the GA/HbAlc ratio was more higher than that between fasting $\mathrm{G}$-peptide and GA. Considering the fact that the fasting C-peptide level means endogenous insulin secretory function, our results showed the higher the insulin secretory function, the GA/HbAlc ratio declines further. A recent studies support GA level has more correlation with postprandial glucose concentration than mean plasma glucose level, comparing with HbAlc level ${ }^{11,22,23)}$. The reasons why serum GA reflects postprandial glucose level better than $\mathrm{HbAlc}$ are still unknown. It can be considered that because of the higher insulin secretory function, smaller increase in postprandial glucose, the GA/HbAlc ratio decreases.

Some limitations of our study are as follows: This study had small number of cases and a limited cross-sectional method. Also we didn't collect the data of postprandial parameter such as plasma glucose, C-peptide level and therefore did not entirely verify the above finding.

Nonetheless, our study is meaningful as a first study about serum GA level and GA/HbAlc ratio in pediatric diabetes. It will be helpful for GA level and GA/HbAlc ratio to be used in the assessment of intermediate-term glycemic control in pediatric DM patients. The further studies are needed in pediatric diabetic patients.

\section{Conflict of interest}

No potential conflict of interest relevant to this article was reported.

\section{Acknowledgments}

This work was supported by the research fund of Inha University.

\section{References}

1. Tahara Y, Shima K. Kinetics of HbAlc, glycated albumin, and fructosamine and analysis of their weight functions against preceding plasma glucose level. Diabetes Care 1995;18:440-7.

2. Panzer S, Kronik G, Lechner K, Bettelheim P, Neumann E, Dudczak R. Glycosylated hemoglobins (GHb): an index of red cell survival. Blood 1982;59:1348-50.

3. Jeffcoate SL. Diabetes control and complications: the role of glycated haemoglobin, 25 years on. Diabet Med 2004;21:657-65.

4. Bry L, Chen PC, Sacks DB. Effects of hemoglobin variants and chemically modified derivatives on assays for glycohemoglobin. Clin Chem 2001;47:153-63.

5. Song MK, Bae JW, Kim YH, Chung S. Hemoglobin A1c in the screening of obesity-related diseases in children and adolescents. Ann Pediatr Endocrinol Metab 2012:17:92-9.

6. Koga M, Hashimoto K, Murai J, Saito H, Mukai M, Ikegame $\mathrm{K}$, et al. Usefulness of glycated albumin as an indicator of glycemic control status in patients with hemolytic anemia. Clin Chim Acta 2011;412:253-7.

7. Hashimoto K, Osugi T, Noguchi S, Morimoto Y, Wasada $\mathrm{K}$, Imai S, et al. A $\mathrm{CC}$ but not serum glycated albumin is elevated because of iron deficiency in late pregnancy in diabetic women. Diabetes Care 2010;33:509-11.

8. Inaba M, Okuno S, Kumeda Y, Yamada S, Imanishi Y, Tabata T, et al. Glycated albumin is a better glycemic indicator than glycated hemoglobin values in hemodialysis patients with diabetes: effect of anemia and erythropoietin injection. J Am Soc Nephrol 2007;18:896-903.

9. Ai M, Otokozawa S, Schaefer EJ, Asztalos BF, Nakajima K, Shrader P, et al. Glycated albumin and direct low density lipoprotein cholesterol levels in type 2 diabetes mellitus. Clin Chim Acta 2009;406:71-4.

10. Kouzuma T, Usami T, Yamakoshi M, Takahashi M, Imamura S. An enzymatic method for the measurement of glycated albumin in biological samples. Clin Chim Acta 2002;324:61-71.

11. Yoshiuchi K, Matsuhisa M, Katakami N, Nakatani Y, 
Sakamoto K, Matsuoka T, et al. Glycated albumin is a better indicator for glucose excursion than glycated hemoglobin in type 1 and type 2 diabetes. Endocr J 2008;55:503-7.

12. Koga M, Murai J, Saito H, Kasayama S, Imagawa A, Hanafusa T, et al. Serum glycated albumin to haemoglobin $\mathrm{A}$ (1C) ratio can distinguish fulminant type 1 diabetes mellitus from type 2 diabetes mellitus. Ann Clin Biochem 2010;47(Pt 4):313-7.

13. Kim D, Kim KJ, Huh JH, Lee BW, Kang ES, Cha BS, et al. The ratio of glycated albumin to glycated haemoglobin correlates with insulin secretory function. Clin Endocrinol (Oxf) 2012;77:679-83.

14. Koga M, Murai J, Saito H, Kasayama S. Glycated albumin and glycated hemoglobin are influenced differently by endogenous insulin secretion in patients with type 2 diabetes. Diabetes Care 2010;33:270-2.

15. Korea Centers for Disease Control and Prevention, Division of Chronic Disease Surveillance, Committee for the Development of Growth Standard for Korean Children and Adolescents; Korean Pediatric Society, Committee for School Health and Public Health Statistics. 2007 Korean children and adolescents growth standard (commentary for the development of 2007 growth chart). Cheongwon: Korea Centers for Disease Control and Prevention, Division of Chronic Disease Surveillance, 2007.
16. Armbruster DA. Fructosamine: structure, analysis, and clinical usefulness. Clin Chem 1987;33:2153-63.

17. Mosca A, Carenini A, Zoppi F, Carpinelli A, Banfi G, Ceriotti F, et al. Plasma protein glycation as measured by fructosamine assay. Clin Chem 1987;33:1141-6.

18. Schleicher ED, Mayer R, Wagner EM, Gerbitz KD. Is serum fructosamine assay specific for determination of glycated serum protein? Clin Chem 1988;34:320-3.

19. Suwa T, Ohta A, Matsui T, Koganei R, Kato H, Kawata T, et al. Relationship between clinical markers of glycemia and glucose excursion evaluated by continuous glucose monitoring (CGM). Endocr J 2010;57:135-40.

20. Lee EY, Lee BW, Kim D, Lee YH, Kim KJ, Kang ES, et al. Glycated albumin is a useful glycation index for monitoring fluctuating and poorly controlled type 2 diabetic patients. Acta Diabetol 2011;48:167-72.

21. Nathan DM, Kuenen J, Borg R, Zheng H, Schoenfeld D, Heine RJ, et al. Translating the A1C assay into estimated average glucose values. Diabetes Care 2008;31:1473-8.

22. Rhee EJ, Choi JH, Yoo SH, Bae JC, Kim WJ, Choi ES, et al. The association of unintentional changes in weight, body composition, and homeostasis model assessment index with glycemic progression in non-diabetic healthy subjects. Diabetes Metab J 2011;35:138-48.

23. Rhee SY, Woo JT. The prediabetic period: review of clinical aspects. Diabetes Metab J 2011;35:107-16. 